СД-13.

\title{
ТВЕРДОФАЗНЫЙ ВОЛЬТАМПЕРОМЕТРИЧЕСКИЙ АНАЛИЗ НАНОСТРУКТУРИРОВАННЫХ СИСТЕМ НА ОСНОВЕ МЕТАЛЛОВ ПОДГРУППЫ ЖЕЛЕЗА
}

Иванова Н.В. ${ }^{1}$, Иванов Н.Н. ${ }^{2}$, Лобанов А.А. ${ }^{1}$, Захаров Ю.А. ${ }^{1,2}$, Пугачев В.М., ${ }^{1}$ Колмыков Р.П. ${ }^{2}$

${ }^{1}$ ФГБОУ ВО «Кемеровский государственный университет», Кемерово, Россия

${ }^{2}$ Федеральный исследовательский центр угля и углехимии СО РАН, Кемерово, Россия sayganta@mail.ru

DOI: 10.26902/ASFE-11_106

Наноструктурированные (НC) бинарные системы на основе металлов подгруппы железа характеризуются уникальными магнитными и каталитическими свойствами, этим определяется разнообразие областей применения таких систем в виде тонких пленок, порошков и систем «магнитное ядро - инертная оболочка». Функциональные свойства указанных систем используются при создании средств магнитной записи, катализаторов, электрохимических сенсоров, диагностических и лекарственных средств, в том числе, для лечения онкологических заболеваний. В связи с этим актуальной является проблема разработки экспрессных методов анализа НС систем на предмет фазового и элементного состава, а также пространственного расположения фаз. Целью работы является исследование электрохимического отклика и выбор условий вольтамперометрического анализа НС бинарных систем $\mathrm{Pt}-\mathrm{Co}(\mathrm{Fe}), \mathrm{Cd}-\mathrm{Ni}(\mathrm{Cu}), \mathrm{Fe}-\mathrm{Co}(\mathrm{Ni})$ и систем «ядро-оболочка» $\mathrm{Co}(\mathrm{Ni}) / \mathrm{Au}, \mathrm{Fe}-$ $\mathrm{Pt} / \mathrm{Au}, \mathrm{Ni} / \mathrm{Ag}$.

Вольтамперометрические (ВА) исследования проводились с использованием потенциостатов/гальваностатов Parstat 4000 и Versastat 3 в трехэлектродной ячейке со стеклоуглеродными индикаторным и вспомогательным электродами, и хлоридсеребряным электродом сравнения. Исследуемые НС системы, полученные методом электролитического и химического восстановления [1,2], наносились на поверхность индикаторных электродов. Предварительно для каждого металла выбирались условия формирования воспроизводимого сигнала, линейно зависящего от концентрации соответствующих ионов, вводимых в электролизёр. Установлено, что в качестве фоновых электролитов могут быть использованы кислые сульфатные, хлоридные, а также аммиачные среды. В результате проведенных исследований разработаны методики анализа фазового состава указанных НС систем, заключающиеся в сочетании различных вариантов циклической и инверсионной вольтамперометрии. Каждая методика включает определенную последовательность выполнения электрохимических операций, позволяющих определить фазовый состав, а также, при необходимости, целостность оболочки из благородного металла, опираясь на потенциал пика окисления/восстановления и трансформацию параметров пика при варьировании условий. Корректность предлагаемых методик подтверждена методами рентгенофазового анализа и ИСП АЭС. Показана возможность проведения последовательного элементного ВАанализа биметаллических систем после проведения соответствующей пробоподготовки.

\section{Список литературы}

1. Zaharov, Y., Pugachev, V., Datiy, K., Popova, A., Valnyukova, A. and Bogomyakov, A. Key Engineering Materials, 2015, vol. 670, p. 49-54.

2. Ivanova, N., Ivanova, E., Lobanov, A., Mikhailik, T., Pugachev, V., Zakharov, Yu. and Valnyukova A. IOP conference series: Materials science and engineering, 2019, p. 012019.

Авторы выражают благодарность Поповой А.Н. и Вальнюковой А.С. за предоставленнье образцьь наноструктурированных порошков. 